\title{
PDIA6 Gene
}

National Cancer Institute

\section{Source}

National Cancer Institute. PDIA6 Gene. NCI Thesaurus. Code C128479.

This gene plays a role in protein folding and platelet aggregation. 